\title{
Luaran Pasien Anak dengan Gagal Ginjal Terminal
}

\author{
Oke Rina Ramayani, Rosmayanti, Rafita Ramayati, Rusdidjas \\ Departemen Ilmu Kesehatan Anak, RS H. Adam Malik, Medan
}

Latar belakang. Gagal ginjal terminal merupakan kondisi yang tidak reversibel dan berlanjut pada kematian. Hal tersebut masih merupakan penyebab penting morbiditas dan mortalitas pada anak.

Tujuan. Penelitian bertujuan untuk mengetahui etiologi dan modalitas terapi pasien gagal ginjal terminal. Metode. Penelitian retrospektif dengan melakukan telaah rekam medis terhadap 38 anak yang didiagnosis gagal ginjal terminal antara tahun 2005-2010 di RS H.Adam Malik, Medan.

Hasil. Selama penelitian, 38 anak (38/355) terdiagnosis gagal ginjal terminal di antara keseluruhan anak penyakit ginjal di RS H. Adam Malik, Medan. Selama kurun waktu tersebut 41.130 anak berobat di Bagian Anak atau lebih kurang 0,1\%. Dua puluh lima anak di antaranya (25/38) adalah laki-laki. Rerata umur saat datang pertama kali 9,8 tahun. Penyebab utama gagal ginjal terminal adalah glomerulonefritis kronik (24/38), pielonefritis kronik (5/38), hidronefrosis (2/38) dan penyebab lain (7/38). Modalitas terapi untuk pasien tersebut adalah hemodialisis (17/38), dialisis peritoneal mandiri berkesinambungan (DPMB) (4/38), hemodialisis diikuti DPMB (1/38) dan terapi konservatif /menolak dialisis (16/38). Dua puluh empat anak (24/38) meninggal, 7 anak (7/38) tidak dapat dipantau, dan 7 anak lagi bertahan hidup.

Kesimpulan. Glomerulonefritis kronik merupakan penyebab utama gagal ginjal terminal pada anak di RS H Adam Malik, Medan.Angka mortalitas pasien anak dengan gagal ginjal terminal masih tinggi.

Sari Pediatri 2013;14(5):277-82.

Kata kunci: penyakit ginjal kronik, gagal ginjal terminal, glomerulonefritis, terapi pengganti ginjal

$\mathrm{P}$ enyakit ginjal kronik per definisi adalah kerusakan ginjal (secara patologis, abnormalitas pada uji darah, urin, pencitraan), atau laju filtrasi glomerulus lebih kecil dari $60 \mathrm{~mL} /$ menit $/ 1,73 \mathrm{~m}^{2}$ untuk lebih dari 3 bulan. ${ }^{1}$ Penyakit

\footnotetext{
Alamat korespondensi:

Dr. Oke Rina Ramayani Sp.A, Departemen Ilmu Kesehatan Anak FK USU/ RS H. Adam Malik, Jl Bunga Lau No 1 Medan. Telp: (061) 8365663.
}

ginjal kronik terutama gagal ginjal terminal merupakan penyakit dengan morbiditas dan mortalitas yang tinggi disertai dengan berbagai masalah gangguan tumbuh kembang dan gangguan psikososial. Keseluruhan hal tersebut mempunyai dampak terhadap kualitas hidup anak. $^{2}$

Perawatan anak dengan penyakit ginjal kronik merupakan perawatan berkesinambungan sejak periode penyakit ginjal kronik tahap awal (derajat satu) hingga tahap terminal. ${ }^{1} \mathrm{Hal}$ tersebut sulit dilakukan 
pada anak di negara berkembang karena faktor pengetahuan, ketersediaan dana, dan faktor lain seperti agama/kepercayaan dan sosial budaya. Oleh karena itu, hal yang sering terjadi adalah pasien penyakit ginjal kronik datang ke rumah sakit sudah dalam keadaan gagal ginjal terminal.

Penurunan laju filtrasi glomerulus di bawah 30 $\mathrm{mL} /$ menit/1,73 $\mathrm{m}^{2}$ dapat menimbulkan efek pada pasien penyakit ginjal kronik, misalnya gangguan keseimbangan cairan/elektrolit, asidosis metabolik, gagal tumbuh, dan osteodistrofi renal. Hal tersebut semakin berat apabila penurunan laju filtrasi glomerulus di bawah $15 \mathrm{~mL} /$ menit $/ 1,73 \mathrm{~m}^{2}$ (gagal ginjal terminal) karena menimbulkan komplikasi mayor seperti kardiomiopati, ensefalopati, dan neuropati. Komplikasi akan sulit ditangani kecuali dengan terapi pengganti ginjal. Modalitas terapi pengganti ginjal terdiri atas hemodialisis, dialisis peritoneal mandiri berkesinambungan (DPMB), dan transplantasi ginjal. ${ }^{3,4}$

Keberhasilan terapi pengganti ginjal setiap rumah sakit dipengaruhi oleh faktor internal (adaptasi pasien dan keluarga), serta faktor eksternal (pengalaman, ketersediaan alat, dan biaya). Hal itu berarti perlu kerja sama berbagai pihak seperti pasien, orangtua, pelayan kesehatan (dokter dan perawat), pihak rumah sakit, dan pemerintah. ${ }^{5}$

Data mengenai luaran pasien gagal ginjal terminal, kemungkinan penyebab, dan modalitas terapi yang telah diberikan masih terbatas di negara berkembang termasuk juga di rumah sakit pendidikan H. Adam Malik, Medan. Penelitian kami bertujuan mengetahui penyebab, modalitas terapi pengganti ginjal, dan luaran anak gagal ginjal terminal yang berobat ke RS H.Adam Malik antara tahun 2005 hingga 2010.

\section{Metode}

Penelitian retrospektif, data diambil dari catatan medis anak dengan gagal ginjal terminal yang berobat ke RS $\mathrm{H}$. Adam Malik antara tahun 2005 hingga 2010. Diagnosis gagal ginjal terminal ditegakkan apabila laju filtrasi glomerulus di bawah $15 \mathrm{~mL} / \mathrm{menit} / 1,73 \mathrm{~m}^{2}$ ataupun di antara $15-30 \mathrm{~mL} / \mathrm{menit} / 1,73 \mathrm{~m}^{2}$ disertai gejala klinis maupun pemeriksaan radiologis/ultrasonografi yang menyokong tanda-tanda penyakit ginjal tahap akhir. Data yang dikumpulkan meliputi umur, jenis kelamin, penyebab gagal ginjal terminal, modalitas terapi, lama sakit, dan luaran anak pasien gagal ginjal terminal. Data dihubungkan dengan modalitas terapi yang dipergunakan. Semua pasien telah diperiksa,menjalani penilaian, dan evaluasi dalam rangka menegakkan diagnosis/penyebab serta penyebab kematian (apabila ada) oleh dokter spesialis anak, tetapi tidak dilakukan analisis post mortem. Keadaan hilang dan tidak dapat dipantau (loss to follow up) disebutkan jika pasien/keluarga tidak kembali berobat setelah hari terakhir kunjungan ke rumah sakit Data dikumpulkan dan diolah kemudian disajikan dalam bentuk tabulasi dan grafik.

\section{Hasil}

Selama penelitian, 38 anak terdiagnosis gagal ginjal terminal di antara 355 pasien penyakit ginjal. Selama kurun waktu tersebut, terdapat 41.130 anak atau lebih kurang $0,1 \%$ dari pasien anak yang berobat di Bagian Anak RS Adam Malik, Medan. Karakteristik klinis anak gagal ginjal terminal tertera pada Tabel 1. Rerata umur pasien 9,8 tahun, umur termuda 3 tahun dan tertua 15 tahun. Anak laki- laki 25 orang dan perempuan 13 orang. Glomerulonefritis kronis merupakan penyebab

Tabel 1. Karakteristik subjek

\begin{tabular}{lc}
\hline Karakteristik & Frekuensi \\
\hline Umur (tahun), rerata SD & $9,8(3,5)$ \\
Jenis kelamin, $\mathrm{n}$ & \\
$\quad$ Laki-laki & 25 \\
$\quad$ Perempuan & 13 \\
Diagnosis, n & \\
$\quad$ Glomerulonefritis kronik & 24 \\
$\quad$ Pielonefritis kronik & 5 \\
$\quad$ Hidronefrosis & 2 \\
$\quad$ Lain-lain & 7 \\
Terapi pengganti, n & \\
$\quad$ Hemodialisis & 17 \\
DPMB & 4 \\
Konservatif & 16 \\
Hemodialisis dan DPMB & 1 \\
Lama hidup (hari), rerata (SD) & $42,0(51,8)$ \\
Berat badan (kg), rerata (SD) & $23,5(8,1)$ \\
Tinggi badan (cm), rerata (SD) & $123,9(18,4)$ \\
BMI, n & \\
$\quad<$ persentil 3 & 20 \\
persentil 3-97 & 17 \\
>persentil 97 & 1 \\
\hline
\end{tabular}




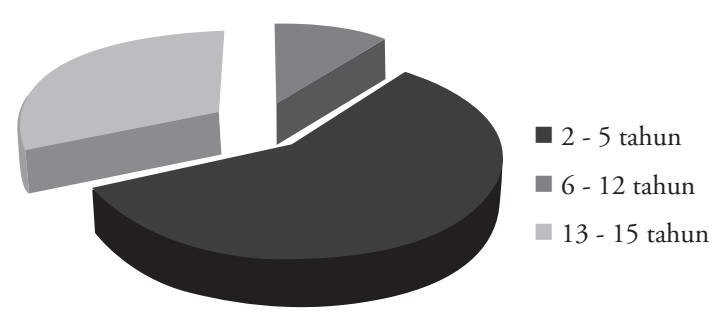

Gambar 1. Distribusi pasien gagal ginjal terminal berdasarkan umur saat pertama diagnosis

Tabel 2. Hubungan luaran klinis dengan kelompok umur pasien gagal ginjal terminal

\begin{tabular}{lcc}
\hline Luaran klinis & $\mathrm{n}$ & $\mathrm{p}$ \\
\hline Hidup (tahun) & & $0,25^{*}$ \\
$\quad<5$ & 0 & \\
$5-10$ & 2 & \\
$\quad 11-17$ & 5 & \\
Jumlah & 7 & \\
Meninggal (tahun) & & \\
$\quad<5$ & 3 & \\
$5-10$ & 12 & \\
$11-17$ & 9 & \\
Jumlah & 24 & \\
Hilang tidak terpantau & 7 & \\
*uji kai kuadrat antara hidup dan meninggal pada berbagai \\
kelompok umur
\end{tabular}

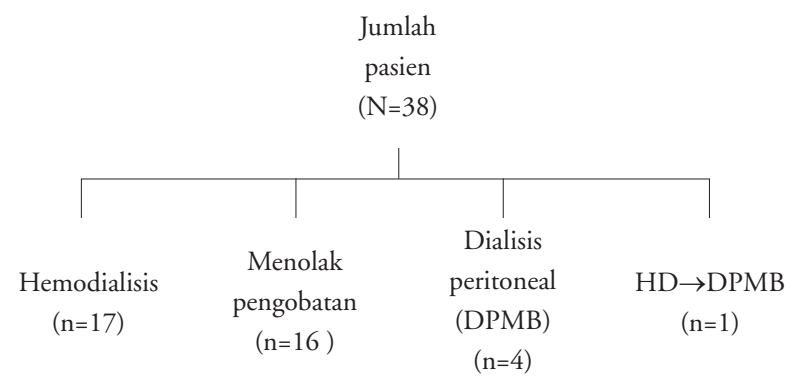

Gambar 2, Modalitas terapi 38 pasien gagal ginjal terminal

terbanyak (24/38) diikuti dengan pielonefritis kronik (5/38), hidronefrosis (2/38), dan diagnosis lain (7/38). Modalitas terapi pengganti ginjal tersering dilakukan adalah hemodialisis 17 anak dan dialisis peritoneal mandiri berkesinambungan (DPMB) 4 anak. Sebelas anak dari kelompok hemodialisis meninggal, 4 masih bertahan hidup, dan 2 hilang. Kelompok DPMB 2 meninggal dan 2 masih bertahan hidup. Enambelas anak menolak dilakukan terapi pengganti ginjal oleh karena berbagai sebab, seperti masalah dana, masalah kepercayaan, dan masalah hubungan dokter dengan pasien yang tidak akrab. Sebelas dari 16 anak yang menolak pengobatan meninggal sedangkan 5 orang hilang/tidak terpantau. (Gambar 2 dan 3, Tabel 2). Komplikasi penyebab kematian dan alasan penolakan terapi tertera pada Tabel 5.

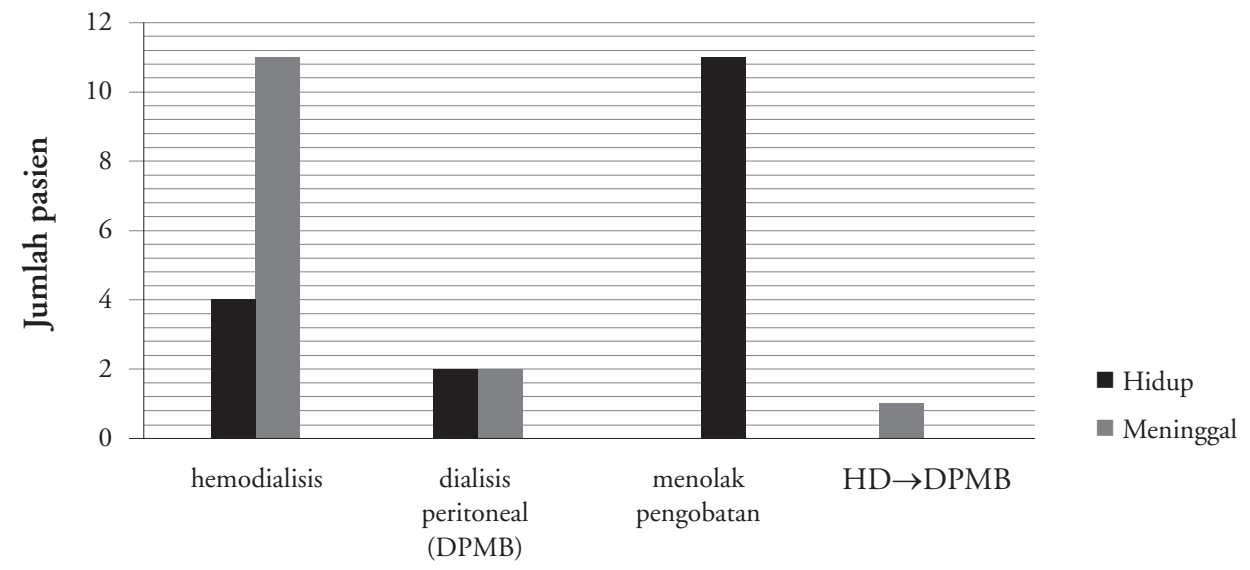

Modalitas terapi

Gambar 3. Hubungan modalitas terapi dengan luaran klinis 
Rentang umur pasien 6-12 tahun merupakan umur terbanyak pasien gagal ginjal terminal seperti tertera pada Gambar 1. Umur tersebut merupakan usia sekolah, sehingga terapi pengganti ginjal sering mengalami hambatan apabila kesadaran anak dan orangtua masih rendah tentang pentingnya terapi pengganti ginjal untuk kelangsungan hidup pasien.

Keberhasilan terapi DPMB lebih tinggi dibandingkan hemodialisis walaupun demikian angka keberhasilan terapi masih tetap rendah secara keseluruhan $(\mathrm{p}=0,037)$. Lama hidup antara modalitas hemodialisis dan DPMB juga tidak berbeda bermakna $(\mathrm{p}=0,615)$. (Tabel 3 dan 4)

Tabel 3. Analisis hubungan modalitas terapi dengan luaran klinis

\begin{tabular}{lccc}
\hline Modalitas terapi & Hidup & Meninggal & $\mathrm{p}$ \\
\hline Hemodialisis & 4 & 11 & $0,037^{*}$ \\
DPMB & 2 & 2 & \\
Menolak & 0 & 11 & \\
Hemodialisis $\rightarrow$ DPMB & 1 & 0 & \\
Total & 7 & 24 & \\
\hline
\end{tabular}

*uji kai kuadrat

Tabel 4. Analisis lama hidup dibandingkan modalitas terapi

\begin{tabular}{lcc}
\hline Modalitas terapi & Lama hidup (hari \pm SEM) & $\mathrm{p}$ \\
\hline Hemodialisis & $46 \pm 16$ & $0,615^{* *}$ \\
DPMB & $30 \pm 2,8$ & \\
\hline
\end{tabular}

** uji Anova

Tabel 5. Komplikasi penyebab kematian dan alasan penolakan terapi pengganti ginjal

\begin{tabular}{lc}
\hline Komplikasi/alasan penolakan & $\mathrm{n}$ \\
\hline Komplikasi penyebab kematian & \\
$\quad$ Perdarahan & 1 \\
Sepsis & 10 \\
Henti jantung & 3 \\
Edema paru & 8 \\
$\quad$ Peritonitis & 2 \\
Alasan penolakan terapi & \\
Tidak ada dana & 4 \\
Masalah kepercayaan & 2 \\
Kepasrahan "berlebihan" & 7 \\
Hubungan dokter pasien tidak akrab & 3 \\
\hline
\end{tabular}

\section{Pembahasan}

Insidens anak dengan gagal ginjal terminal bervariasi di berbagai kawasan dunia. Menurut European dialysis and tramsplant association (EDTA), insidens mencapai 4,5 anak per tahun per seribu anak di bawah umur 15 tahun. ${ }^{6}$ Pada penelitian kami prevalensi pasien gagal ginjal terminal dalam 5 tahun adalah 38 orang (kira-kira 7 anak per tahun) atau 0,1\% dari seluruh kunjungan pasien anak ke rumah sakit $\mathrm{H}$. Adam Malik Medan. Persentase pasien gagal ginjal terminal menunjukkan kecenderungan meningkat terutama pada umur remaja muda, ${ }^{7}$ Hal tersebut sangat memprihatinkan mengingat kualitas hidup anak sebagai generasi penerus bangsa.

North American Pediatrics Renal Trials and Collaborative Studies (NAPRTCS) melaporkan persentase anak yang memulai dialisis, yaitu pada rentang umur 2 hingga 5 tahun (10,3\%), 6-12 tahun (30,7\%), 13-17 tahun (38,5\%), dan di atas 17 tahun $(7,4 \%){ }^{8}$ Hal tersebut menunjukkan bahwa rentang umur 6-12 tahun dan 13-17 tahun memiliki persentase yang tinggi dibandingkan rentang umur yang lebih muda. Keadaan tersebut tidak berbeda jauh dengan di RS H. Adam Malik, yaitu tindakan dialisis pada anak dengan gagal ginjal terminal pada rentang umur 6-12 tahun dan 1315 tahun lebih banyak dibandingkan 2-5 tahun.

Pada rentang umur di atas 5 tahun, etiologi terbanyak gagal ginjal terminal adalah kelainan ginjal didapat (acquired), sebaliknya di bawah 5 tahun lebih sering disebabkan kelainan struktural. ${ }^{6}$ Kelainan kongenital ginjal, saluran kemih, dan nefropati herediter mencapai dua pertiga dari seluruh kasus gagal ginjal terminal pada anak di negara maju sedangkan penyebab didapat lebih banyak dijumpai di negara berkembang. ${ }^{7}$ Data dari Australia dan Selandia Baru menunjukkan tiga penyebab terbanyak gagal ginjal terminal pada anak adalah glomerulonefritis 32,5\%, kelainan struktural (hipoplasia/dysplasia, katup uretra posterior atau refluks nefropati) $35,8 \%$, dan penyakit kista $31,7 \% .{ }^{8}$ Pada penelitian kami didapatkan rerata umur anak yang memulai dialisis adalah 9,8 tahun, dan diagnosis glomerulonefritis kronis lebih sering kami jumpai pada umur tersebut. Diagnosis kelainan struktural menunjukkan kecenderungan meningkat oleh karena perbaikan sarana dan prasarana alat diagnostik untuk kelainan tersebut. Kesadaran orangtua dan tenaga medis juga lebih baik untuk memeriksakan bayi/anak dengan kelainan ginjal/saluran kemih. 
Angka kematian anak dengan gagal ginjal terminal 30 kali lebih tinggi dibandingkan anak tanpa penyakit ginjal. Faktor risiko kematian pada anak gagal ginjal terminal adalah umur yang terlalu muda (di bawah 1 tahun) dalam memulai terapi pengganti ginjal dan anak dengan dialisis apabila dibandingkan dengan transplantasi ginjal. ${ }^{10}$ Frekuensi pasien anak dengan terapi pengganti ginjal yang bertahan hidup (survivor) di RS Adam Malik lebih tinggi pada kelompok umur remaja muda (umur 11-16 tahun) dan tidak ada yang bertahan hidup pada rentang umur muda (dibawah 5 tahun), walaupun demikian analisis hubungan antara luaran klinis dengan kelompok umur pada saat memulai dialisis tidak bermakna. Angka keberhasilan terapi pasien dialisis masih rendah, hal tersebut disebabkan timbul komplikasi yaitu perdarahan, sepsis, henti jantung, edema paru, dan peritonitis.

Pengalaman di negara maju menunjukkan bahwa kematian karena penyebab kardiovaskular seperti henti jantung, perikarditis, gagal jantung kongestif, kejadian serebrovaskular (41\%) lebih tinggi apabila dibandingkan kejadian sepsis (21\%). Masa dialisis yang relatif lama menyebabkan masa hipertensi yang relatif lebih lama dan berhubungan dengan peningkatan mortalitas akibat penyakit kardiovaskular di negara-negara maju. ${ }^{7,11}$ Kejadian sebaliknya terjadi pada penelitian kami, mengingat sepsis masih tinggi kami temukan sebagai penyebab kematian, dikuti oleh edema paru, peritonitis, dan henti jantung. Kematian umumnya terjadi dalam tahun pertama setelah dimulainya dialisis dengan lama hidup yang rendah pada kedua grup modalitas terapi. Keadaan tersebut masih memprihatinkan mengingat kejadian sepsis seharusnya bisa dicegah dari awal dengan menerapkan kontrol infeksi dan pengembangan teknik dialisis yang adekuat. Kejadian edema paru yang diakibatkan ketidakseimbangan cairan pada saat anak didialisis dan kejadian peritonitis sebagai komplikasi teknik DPMB merupakan petunjuk dari kemampuan penyedia layanan kesehatan yang kurang dalam hal teknik dialisis dan kontrol infeksi yang adekuat. Henti jantung sebagai penyebab kematian di sentra kami juga lebih banyak disebabkan oleh ketidakseimbangan elektrolit (hiperkalemia) daripada karena keadaan hipertensi kronik seperti yang terjadi di negara maju. Hiperkalemia biasa terjadi karena pasien tidak patuh jadwal dialisis maupun diet pasien yang tidak benar.

Pilihan terapi pengganti ginjal di negara maju (seperti Australia dan Selandia Baru) 50\% dengan dialisis peritoneal, $30 \%$ hemodialisis, dan $20 \%$ transplantasi ginjal. ${ }^{8}$ Keadaan tersebut berbeda dengan keadaan pasien di RS H. Adam Malik oleh karena terapi pengganti ginjal seperti hemodialisis dan DPMB lebih sering dilakukan, sedangkan transplantasi ginjal belum dilakukan karena keterbatasan pengalaman, peralatan, dan dana. Transplantasi ginjal sering tidak ditawarkan sebagai pilihan kepada pasien dan keluarga di negara berkembang karena donor meninggal yang kurang sehingga pilihan kepada saudara pasien untuk donor hidup dan jual beli organ donor meningkat. ${ }^{7}$

Terapi konservatif dilakukan pada keluarga yang menolak tindakan dialisis. Tujuan utama terapi konservatif untuk memperlambat progresifitas penurunan laju filtrasi glomerulus, namun apabila sudah dalam keadaan gagal ginjal terminal maka pilihan terapi hanya terapi pengganti ginjal. ${ }^{2}$ Keadaan penolakan terapi merupakan proses yang kompleks dan tidak semata-mata memengaruhi keberhasilan terapi. Keputusan pasien/keluarga untuk menolak terapi didasarkan pada keputusan/ instink pribadi dibandingkan pertimbangan logis. ${ }^{12}$ Beberapa alasan penolakan terapi pengganti ginjal di atas sebenarnya dapat dihindari dengan konseling kepada anak/keluarga dan pendekatan tim (team based approach).

Tata laksana perawatan yang lebih kompleks diperlukan oleh anak dengan gagal ginjal terminal, karena membutuhkan kerja sama berbagai pihak yang berwenang (team based approach). Kerja sama tersebut meliputi kerja sama internal yaitu antara dokter spesialis anak, perawat dialisis, ahli nutrisi anak, psikolog anak, sedangkan kerja sama eksternal antara dokter spesialis anak dengan yayasan penggalang dana (misal Budha Tsu Chi, dll), Palang Merah Indonesia, pekerja sosial, dan pemerintah pada umumnya.

\section{Kesimpulan}

Glomerulonefritis kronis merupakan penyebab terbanyak pasien anak dengan gagal ginjal terminal di RS H. Adam Malik. Angka mortalitas pasien masih tetap tinggi sehingga diperlukan berbagai usaha untuk menurunkannya seperti meningkatkan pengalaman, meningkatkan pengetahuan, keterampilan serta konseling, dan dimulai pengembangan transplantasi ginjal. Kerja sama tim dalam meningkatkan angka harapan hidup pasien dialisis amat diperlukan. 
Oke Rina Ramayani dkk: Luaran pasien anak dengan gagal ginjal terminal

\section{Daftar pustaka}

1. The National Kidney Foundation. Kidney Disease Outcome Quality Initiative 2000 Update. evaluation, classification and stratification. Diunduh dari : http:// www.kidney.org/professionals/kdoqi/guidelines/doqi_upex.html (Diakses 25 April 2011)

2. Shroff R, Lederman S. Long term outcome of chronic dialysis in children. Pediatr Nephrol 2009;24:463-74.

3. Rigden SPA. The management of chronic and end stage renal failure in children. Dalam: Webb NJA, Postlethewaite RJ, penyunting. Clinical pediatric nephrology. Edisi ke-3. Oxford: Oxford University Press; 2003.h.427-45.

4. Chiu MC, Tse KC, Lai WM. Dialysis and renal transplantation in children. HK J Pediatr 2002; 7:230-6.

5. White CT, Trnka P, Matsell DG. Selected primary care issues and comorbidities in children who are on maintenance dialysis: a review for pediatric nephrologist. Clin J Am Soc Nephrol 2007;10:1-11.

6. Broyer M, Chantler C. The Pediatric Registry of the European Dialysis and Transplantation Association: 20 years experience. Pediatr Nephrol 1993;7:758-68.
7. Harambat J, Van Stralen KJ, Kim JJ, Tizard EJ. Epidemiology of chronic kidney disease in children. Pediatr Nephrol 2012; 27:363-73.

8. Orr NI, Mc Donald SP, Mc Taggart S, Henning P, Craig JC. Frequency, etiology and treatment of childhood end stage kidney disease in Australia and New Zealend. Pediatr Nephrol 2009;24:1719-26.

9. Harmon W, Fine R, Alexander S, Warady B, Benfield M, Goldstein S, dkk. North American Pediatric Renal Trials and Collaborative Studies. The 2006 Annual Report NAPRTCS. Massachusetts, Boston, 2006.

10. Mc Donald SP, Craig JC. Long term survival of children with end stage renal disease. $\mathrm{N}$ Engl J Med 2004;350:2654-62.

11. Groothooff JW, Gruppen MP, Offringa M, Hutten J, Lilien MR, Van de Kar NJ dkk. Mortality and causes of death of end stage renal disease in children: A Dutch cohort study. Kidney Int 2002;61:621-9.

12. Al Jahdali HH, Bahroon S, Babgi Y, Tamim H, Al Ghamdi SM, Al Sayyari AA. Advance care planning preferences among dialysis patients and factors influencing their decisions. Saudi J Kidney Dis Transpl 2009;20:232-9. 